\title{
Conjunctival Melanoma cT1c TNM Finding v8
}

National Cancer Institute

\section{Source}

National Cancer Institute. Conjunctival Melanoma CT1C TNM Finding v8. NCI Thesaurus. Code C140567.

Conjunctival melanoma with tumor of the bulbar conjunctiva, involving 2 or more to less than 3 quadrants. (from AJCC 8th Ed.) 